\title{
Sublethal effects in Perinereis gualpensis (Polychaeta: Nereididae) exposed to mercury-pyrene sediment mixture observed in a multipolluted estuary
}

\author{
M. Díaz-Jaramillo ${ }^{1,2}$ - K. S. B Miglioranza ${ }^{2}$ P. Carriquiriborde ${ }^{3}$ - D. Marino ${ }^{3}$ • \\ C. N Pegoraro ${ }^{4}$ - G. Valenzuela ${ }^{5}$ R. Barra ${ }^{1}$
}

Accepted: 20 April 2017 / Published online: 3 May 2017

(C) Springer Science+Business Media New York 2017

\begin{abstract}
Sediment-living organisms can be subjected to a multi-pollution condition due to an increase in the diversity of contaminants. Sediment mixtures of Mercury $(\mathrm{Hg})$ and some polycyclic aromatics hydrocarbons like Pyrene (Pyr) are common in heavily industrialized coastal zones. In the present study, greater than $(>)$ and less than $(<)$ probable effect concentration levels (PELs) of $\mathrm{Hg}$ and $\mathrm{Pyr}$ were assessed using spiked sediments in order to determine combined $(\mathrm{Hg}+\mathrm{Pyr})$ effects in uptake, metabolization and oxidative balance in the polychaete Perinereis gualpensis at short and medium-term exposure. $\mathrm{Hg}+\mathrm{Pyr}$ significantly influenced the uptake/kinetics of $\mathrm{Hg}$ and Pyr metabolite 1$\mathrm{OH}-$ pyrene in polychaete tissues during the exposure time compared with separate treatments of each analyte $(p<$ 0.05). Both the Hg-only and Pyr-only exposures significantly influenced both enzymatic and non-enzymatic responses respect to control groups $(p<0.05)$. The Hg-only
\end{abstract}

M. Díaz-Jaramillo

mdiazjaramillo@conicet.gov.ar

1 Departamento de Sistemas Acuáticos, Facultad de Ciencias Ambientales \& Centro EULA-Chile, Universidad de Concepción, Concepcion, Chile

2 IIMyC, UNMdP, CONICET, Laboratorio de Ecotoxicología y Contaminación Ambiental, Funes 3350 (B7602AYL), Mar del Plata 7600, Argentina

3 Centro de Investigaciones del Medio Ambiente, Facultad de Ciencias Exactas, Universidad Nacional de La Plata- CONICET, La Plata, Argentina

4 Departamento de Química, Facultad de Ciencias Exactas y Naturales, Universidad Nacional de Mar del Plata-CONICET, Mar del Plata, Argentina

5 Instituto de Ciencias Marinas y Limnológicas, Facultad de Ciencias, Universidad Austral de Chile, Valdivia, Chile treatment showed the worst scenario related to the activation and subsequent inhibition of glutathione S- transferase (GST) and peroxidase (GPx) activities, high levels of Thiolgroups (SH-groups), low antioxidant capacity (ACAP) and enhanced lipid peroxidation (TBARS) in the last days of exposure $(p<0.05)$. In contrast, ragworms exposed to $\mathrm{Hg}$ + Pyr showed a significant increase in both enzymatic and non-enzymatic activity during the first days of exposure and the absence of lipid peroxidation during the whole experiment. Our results suggest different oxidative stress scenarios in $P$. gualpensis when exposed to $>\mathrm{PEL} \mathrm{Hg}$ concentration with $<$ PEL Pyr in sediments. Results also reveal the importance of the exposure time, endpoints involved as well as of the contaminant monitoring during the whole experiments in assessing the interactive effects of the contaminant mixture.

Keywords Mercury Pyrene $\cdot$ Mixture $\cdot$ Oxidative stress • Spiked sediments

\section{Introduction}

Estuarine sediments are important sinks of the contaminants originated by several anthropogenic activities (AmiardTriquet and Rainbow 2009). These activities have led to an increase in aquatic contaminants not only in terms of quantity but also in terms of variety (Newman and Unger 2003; UNEP 2013). Interactions of contaminants in mixtures can lead to diverse biochemical pathways and consequently trigger different and unpredictable toxicological responses in aquatic organisms (Maria and Bebbiano 2011; Wang et al. 2011). 
Polycyclic aromatic hydrocarbons (PAHs) and nonessential metals represent aquatic contaminants of high environmental concern due to their ubiquity and welldocumented effects on the biota (Gauthier et al. 2014). Due to the occurrence of industrial clusters linked to chlor-alkali and oil-related industries, Mercury ( $\mathrm{Hg}$ ) and Pyrene (Pyr) are likely to appear individually and simultaneously in coastal/estuarine environments in concentrations above and below to some SQG respectively (MacDonald et al. 2000; CCME 2002; Mai et al. 2002; Cachot et al. 2006; Pozo et al. 2011; Díaz-Jaramillo et al. 2013; Yañez et al. 2013). Pyr, which is related to fossil combustion and oil spill events, is one of the dominant PAHs in coastal environments (Richardson et al. 2008; Pozo et al. 2011; Oliveira et al. 2013; Almeida et al. 2012). The toxicity and metabolism of Pyr in marine animals, following short- and long-term exposure, where 1-OH-Pyrene is one of the most important intermediate metabolites, have been studied by several authors (Giessing et al. 2003; Oliveira et al. 2013). Hg, which comes from natural and anthropogenic sources, is a highly toxic non-essential trace element of global concern, whose inputs have substantially increased during the last century (Colacevich et al. 2011). In coastal sediments, urban runoff, industrial discharge and atmospheric deposition are the main anthropogenic sources of the trace element (Stoichev et al. 2004). Although methylmercury (MeHg) is the form of $\mathrm{Hg}$ that represents the most environmental concern regarding $\mathrm{Hg}$, inorganic forms as $\mathrm{Hg}^{2+}$ are also involved (Colacevich et al. 2011). Inorganic $\mathrm{Hg}$ forms are also toxic, being the most important source of biotic and abiotic $\mathrm{Hg}$ methylation and representing more than $95 \%$ respect its organic forms in estuarine sediments (Lund et al. 1993; Stoichev et al. 2004; Yañez et al. 2013). Real scenarios (including estuarine environments) are complex in terms of sediment biogeochemistry and $\mathrm{Hg}$ bioavailability (Ouddane et al. 2008). However, since naturally contaminated sediments generally contain mixtures of toxicants, it is difficult to establish cause-effect relationships (Hutchins 2005). Tracking pollutant uptake/biotransformation during exposure time can yield valuable data to explain the bioavailability and biochemical responses of pollutants.

In terms of sublethal toxicity, trace elements and PAHs cause oxidative stress in aquatic organisms by different toxicological pathways (Almeida et al. 2012; Gauthier et al. 2014). These include direct or indirect formation of Reactive Oxygen Species (ROS) generating oxidative stress burst (Kopecka-Pilarczyk and Correia 2009; Colacevich et al. 2011; Rodrigues et al. 2013). Oxidative stress responses include those of glutathione S-transferase (GST) as a biotransformation phase II enzyme, the antioxidant enzyme glutathione peroxidase (GPx), the intracellular amount of Thiol-groups (SH-groups), the total antioxidant capacity against peroxyl radicals (ACAP) as the sum of enzymatic and non-enzymatic defenses, and Thiobarbituric Reactive Substances (TBARS) as biomarkers of lipid oxidative damage (also referred as LPO). TBARS represent endpoints with high ecotoxicological relevance and thus allow us to elucidate potential oxidative stress scenarios in aquatic organisms (Oakes and Van Der Kraak 2003).

During the last years, the interaction between trace elements and PAHs in aquatic organisms has been increasingly assessed (Gauthier et al. 2014). However, studies have been focused on aqueous media and different metals and PAH compounds (Ahmad et al. 2005; Almeida et al. 2008; Banni et al. 2009; Bouraoui et al. 2009; Maria and Bebbiano 2011; Wang et al. 2011; Vega-López et al. 2013; Gauthier et al. 2014). Therefore, studying the effects of Hg-Pyr mixtures using sediments and soft-bottom benthic animals represents a valuable contribution to understanding the effects of $\mathrm{Hg}$ pollution on multi-polluted environments.

The aim of this study was to examine the single and combined effects of $\mathrm{Pyr}$ and $\mathrm{Hg}$ at environmental relevant concentrations on oxidative stress responses (GST, GPx, SH-groups, ACAP and TBARS), including measurements of $\mathrm{Hg}$ and Pyr in sediments, overlying and pore water plus total $\mathrm{Hg}$ bioaccumulation and 1-OH-pyrene concentrations in the key estuarine species Perinereis gualpensis (ragworm) during short- and medium-term exposure.

Perinereis gualpensis was selected as test organism because it has been used as an effective biomonitor species of $\mathrm{Hg}$ bioaccumulation in sediments (Díaz-Jaramillo et al. 2013). P. gualpensis also provides measurable subindividual responses during short- and medium-term exposure to contaminants (Díaz-Jaramillo et al. 2011).

\section{Material and methods}

\section{Test design}

To determine single and combined effects of $\mathrm{Hg}$ and Pyr on oxidative stress responses, adult individuals of $P$. gualpensis in non-evident reproductive stage $(0.26 \pm 0.04 \mathrm{~g} \mathrm{w}$. w) from the aquaculture facility of the Coastal Laboratory of Aquatic Resources of Calfuco (Universidad Austral de Chile) were exposed separately to sediments spiked with $\mathrm{Hg}$ and Pyr and their mixture. Concentrations were based on environmental $\mathrm{Hg}$ and Pyr levels reported in previous studies from estuarine polluted areas characterized by $\mathrm{Hg}$ pollution legacy from chlor-alkali and Pyr levels related to oil industries. (Table 1; Pozo et al. 2011; Díaz-Jaramillo et al. 2013; Yañez et al. 2013).

Before the experiments, ragworms from aquaculture sediment hatchery were transferred to laboratory keeping with filtered seawater and similar sediment conditions (salinity: 20 PSU, see below test sediment) for $48 \mathrm{~h}$. Four 
Table 1 Ranges and means (in parenthesis) of $\mathrm{Hg}$ and Pyr sediment concentrations observed in different areas from a multipolluted estuary including values of international Sediment Quality Guidelines (SQG) for marine sediments

\begin{tabular}{lll}
\hline Estuarine area & $\mathrm{Hg}(\mathrm{mg} / \mathrm{Kg}$ d.w $)$ & Pyr $(\mathrm{ng} / \mathrm{g} \mathrm{d.w})$ \\
\hline Mouth & $0.4-1.22(0.79)^{\mathrm{a}, \mathrm{b}}$ & $91-369(189)^{\mathrm{c}}$ \\
Central & $1.61-83.0(14.7)^{\mathrm{a}, \mathrm{b}}$ & $36-1017(442)^{\mathrm{c}}$ \\
Head & $1.00-129(43.5)^{\mathrm{b}}$ & $86-953(394)^{\mathrm{c}}$ \\
Total average & 19.2 & 342 \\
SQG & & \\
PEL & 0.70 & 1398 \\
\hline
\end{tabular}

PEL probable effect level

${ }^{\text {a }}$ Díaz-Jaramillo et al. (2013)

${ }^{b}$ Yañez et al. (2013)

${ }^{\mathrm{c}}$ Pozo et al. (2011)

treatments were assessed to obtain sediment exposures from single $\mathrm{Hg}$ and $\mathrm{Pyr}$ sediments and their mixture. A nonspiked control group was run in parallel with the same sediments. Then, 5-7 individuals were transferred to plastic containers with $500 \mathrm{~g}$ of spiked and non-spiked sediments ( $n=3$ containers per treatment/sampling time) with filtered and continuous aerated seawater (salinity: 20 PSU). At the end of each exposure time, surviving ragworms were gently removed from the sediments and frozen in liquid $\mathrm{N}_{2}$ and subsequently stored at $-80{ }^{\circ} \mathrm{C}$ for biochemical analysis. Ragworms were sampled at different times (2, 7, 14 and 21 days) in the control sediments and during the single and combined $\mathrm{Hg}+$ Pyr exposure. Additionally, dead ragworms were daily removed and summarized every 7 days, total mortality was recorded at the end of the exposure time from each treatment. For chemical analysis of $\mathrm{Hg}$ and $\mathrm{Pyr}$ metabolites, ragworms were also sampled at different times (2, 7, 14 and 21 days) and transferred to plastic containers with filtered seawater for $6 \mathrm{~h}$ to allow them to clean their guts, and then stored at $-20^{\circ} \mathrm{C}$, previous to chemical analysis (see below).

\section{Test sediment}

Estuarine natural sediment (Valdivia river estuary; $39^{\circ} 51^{\prime}$ $44.9^{\prime \prime} \mathrm{S} ; 73^{\circ} 20^{\prime} 59.5^{\prime \prime} \mathrm{W}$ ) also utilized for cultured ragworms was used to prepare the control and spiked sediments. The sediment was dried at $80^{\circ} \mathrm{C}$ for $96 \mathrm{~h}$ to homogenize it evenly and eliminate other organisms. The sediment was also sieved through a $400-\mu \mathrm{m}$ mesh to exclude gross sediment particles. This sandy-mud sediment contained $0.5 \%$ of organic carbon, $93.4 \%$ of sand, $4.7 \%$ of clay and $1.9 \%$ of silt. Sediments were spiked with solutions made from $\mathrm{Hg}^{2+}$ as Mercury chloride $\left(\mathrm{HgCl}_{2} ;\right.$ Merck, Germany) and certified Pyrene standard (Dr Ehrenstorfer,
Germany). Desired sediment concentrations for single/ mixture exposures were $20 \mathrm{mg} / \mathrm{kg}$ and $1000 \mu \mathrm{g} / \mathrm{kg} \mathrm{d} . \mathrm{w}$ for Total $\mathrm{Hg}$ and Pyr respectively.

$\mathrm{HgCl}_{2}$ and Pyr were dissolved in ultra-pure water and acetone, respectively and then transferred to the sediments. The sediments were then stored in the dark and placed in a well-ventilated fume hood to dry and evaporate the solvent. Then, dry control and spiked sediments were mixed in overhead shaker for 14 days and stored in the dark at room temperature for 30 days to age and equilibrate. Sediments were additionally equilibrated with filtered seawater (salinity: 20 PSU) for $24 \mathrm{~h}$ prior to the addition of ragworms. Test sediments were run in a temperature-controlled room $\left(15^{\circ} \mathrm{C}\right)$ and exposed to a photoperiod of $10: 14 \mathrm{~h}$ of light: dark, respectively. Experimental conditions of $\mathrm{pH}$ and temperature of seawater were $8.1( \pm 0.1)$ and $13.2\left( \pm 0.6{ }^{\circ} \mathrm{C}\right)$ respectively.

\section{Chemical analysis}

\section{Sample preparation}

For chemical analysis of $\mathrm{Hg}$ and Pyr in sediments, overlying and pore water samples were obtained at 2 and 21 days of exposure. Before ragworms collection, overlying waters and sediments were gently removed from test containers. Test sediments were transported to Geosciences Institute, Universidad Austral de Chile for pore water extraction. Pore water from test sediments was obtained following the methodology described by Mason et al. (1998) with modifications. Briefly Nitrogen positive gas pressure was applied to the top of the core with sediments through the core tube lid. Porewater was squeezed out of the sediment, filtering pore fluid through $0.4 \mu \mathrm{m}$ membrane filter and contained into precleaned bottles.

\section{$\mathrm{Hg}$ in water and sediments}

Total sediment and water $\mathrm{Hg}$ were determined from freezedried sediment, overlying and pore water by cold vapor atomic absorbance spectrometry (CVAAS; Perkin-Elmer FIMS-400, Perkin-Elmer Corp., USA). Sediment and water samples were determined by EPA method 245.5 (USEPA 1991) and standard 3111 method (APHA 2012) respectively. Calibration was done using certified standard (Merck 170226, Darmstadt, Germany) traceable to Standard Reference Materials (SRM). Procedural blanks and SRM PACS-2 from the National Research Council of Canada (NRC, Canada) was included (106\% recovery average; $n=$ $3)$. The detection limit for $\mathrm{Hg}$ in the sample solutions was $0.5 \mu \mathrm{g} / \mathrm{L}$. 


\section{Pyr in water and sediments}

The sample preparation for Pyr analysis was performed according to UNEP/IOC/IAEA (1992). Blanks were prepared to check any possible contamination during the analytical procedure. Samples were analyzed using a Shimadzu GCMS-QP2100ULTRA-AOC20i with a column Zebron ZB-5MS $(30 \mathrm{~m} \times 0.25 \mathrm{~mm} \times 0.10 \mu \mathrm{m})$ in splitless mode and the injection volume was $2 \mu \mathrm{l}$. The interface and the ionization source were kept at 300 and $280{ }^{\circ} \mathrm{C}$ respectively. Electron impact ionization was used at $70 \mathrm{eV}$ in the SIM mode. The oven temperature program was as follows: $80^{\circ} \mathrm{C}$, held for $1 \mathrm{~min}$, increased at $5^{\circ} \mathrm{C} / \mathrm{min}$ to $320^{\circ} \mathrm{C}$, held for 4 min. Surrogate recoveries were estimated from the labeled compounds (napthalene d8; acenapthene d10, Phenanthene d10) spiked prior to extraction. Average surrogate recoveries estimated from napthalene $\mathrm{d} 8$, acenapthene $\mathrm{d} 10$ and Phenanthene spiked prior to extraction were 92, 91 and $72 \%$ respectively. All data were recovery corrected. The target compounds were not detected in procedural blanks. The detection limit for Pyr in the sample solutions was $0.5 \mathrm{ng} / \mathrm{ml}$.

\section{Hg in P. gualpensis tissues}

Total $\mathrm{Hg}$ concentration in $P$. gualpensis tissues was analyzed in freeze-dried ragworms from each sampling time in $\mathrm{Hg}$ and $\mathrm{Hg}+\mathrm{Pyr}$ treatments $(n=3$ per treatment/sampling time) with their respective controls. Total $\mathrm{Hg}$ was determined by CVAAS (see above) according to Díaz-Jaramillo et al. (2013). Procedural blanks and SRM DORM-2 (NRC, Canada) were included ( $112 \%$ recovery average; $n=3)$. The method detection limit was $0.016 \mathrm{mg} / \mathrm{kg}$.

\section{1-OH-Pyr concentration in P. gualpensis tissues}

Quantification of 1-hydroxypyrene (1-OH-Pyr) in P. gualpensis, the most important intermediate $\mathrm{Pyr}$ metabolite observed in polychaetes (Giessing et al. 2003) was performed in order to quantify indirectly $P$. gualpensis $\mathrm{Pyr}$ exposure from test sediments. Quantification of 1-OH-Pyr was performed according to Giessing et al. (2003) with modifications and was analyzed in ragworms from each sampling time in Pyr and $\mathrm{Hg}+\mathrm{Pyr}$ treatments $(n=3-5$ per treatment/sampling time) with their respective controls. Briefly, tissues from ragworms were homogenized in 250 $\mu \mathrm{L}$ of methanol (1:3 weight:solvent). Samples were then centrifuged $(500 \mathrm{~g})$ to precipitate any debris and supernatant was filtered through a $0.22-\mathrm{mm}$ syringe filter and transferred directly to amber HPLC-MS vials. Calibration curves were made by standard of 1-OH-Pyr (Sigma-Aldrich, Germany) in methanol (regression coefficient: $r^{2}>0.99$ ). 1-OH-Pyr was determined by the LC system coupled with a MSD VL quadrupole with an electrospray ionization interface (1100,
Agilent Technologies Inc., USA). The chromatographic separations were performed on a $\mathrm{C}-18$ column on isocratic mode (Acetonitrile: Formic Acid 0.1\%). The electrospray ionization was operated at $330{ }^{\circ} \mathrm{C}$ on positive mode. Analytical procedures were validated using recoveries made with spiked a known standard concentration of 1-0H-Pyr on polychaete tissue. Average recovery of 1-0H-Pyr on spiked polychaete tissue was $70 \%$.

\section{Biochemical analysis}

Protein content, GST and GPx activities and SH-groups concentrations and ACAP were biochemically measured using anterior/medium body regions of ragworms (5-9 organisms/tissues per treatment/sampling time) homogenized in Tris-Sucrose buffer, centrifuged $(9000 \mathrm{~g}$ ) and stored in ultrafreezer $\left(-80^{\circ} \mathrm{C}\right)$ for further analysis (DíazJaramillo et al. 2011). The activity of GST was evaluated according to Habig and Jakoby (1981), the activity of GPx according to Sies et al. (1979), and sulfhydryl content (SHgroups) according to Sedlak and Lindsay (1968). Total Antioxidant capacity against peroxyl radicals (ACAP) was measured according to Amado et al. (2009) high relative difference areas reflecting lower antioxidant capacity. For TBARS measurements, posterior body end of the same ragworm tissues were evaluated according to Oakes and Van Der Kraak using KCl buffer (2003).

\section{Data analysis}

Changes in total $\mathrm{Hg}$ and 1-OH-Pyr tissue concentrations and biochemical responses were evaluated by analysis of variance (ANOVA) using Newman-Keuls test for post-hoc comparisons $(\alpha: 0.05 ; p$ below to 0.01 expressed as $<0.01)$. Data were checked to meet the assumptions of normality and homogeneity of variances prior to analysis. Data without normal distribution were analyzed using Kruskal-Wallis non-parametric test. Additionally, to visualize the overall biochemical responses and their differences between single treatments and the $\mathrm{Hg}+\mathrm{Pyr}$ mixture, a principal component analysis (PCA) was performed.

\section{Results}

In the bioassay test, total ragworm mortality at the end of the exposure period (21 days) was as follows: $13 \%$ in the control, $31 \%$ in the treatment with $\mathrm{Hg}, 29 \%$ in the treatment with Pyr and $23 \%$ in the treatment with both $\mathrm{Hg}$ and Pyr. Statistical analysis showed no significant differences between groups $(p>0.05)$. Total $\mathrm{Hg}$ and Pyr concentrations in the spiked dried sediments prior to used in bioassays 
were $21.5 \pm 1.5 \mathrm{mg} \mathrm{Hg} / \mathrm{kg}$ d.w. and $1328.7 \pm 262.8 \mu \mathrm{g} \mathrm{Pyr} /$ $\mathrm{kg}$ d.w respectively.

\section{Hg and Pyr in sediments and water}

Regarding $\mathrm{Hg}$ and $\mathrm{Pyr}$ concentrations, test sediments (controls) had 0.01 to $0.09 \mathrm{mg}$ of total $\mathrm{Hg} / \mathrm{kg}$ d.w. and 0.28 to $7.93 \mu \mathrm{g} \mathrm{Pyr} / \mathrm{kg}$ d.w (Table 2). In terms of overlying and pore water, $\mathrm{Hg}$ and $\mathrm{Pyr}$ concentrations from controls

Table 2 Total $\mathrm{Hg}$ (bold) and $\mathrm{Pyr}$ (cursive) ranges $(n=2)$ in sediments, overlying and pore water from control, single $\mathrm{Hg} / \mathrm{Pyr}$ and combined $\mathrm{Hg}+\mathrm{Pyr}$ mixture at 2 and 21 days of $P$. gualpensis exposure

\begin{tabular}{|c|c|c|c|}
\hline Compartment & Treatment & Day 2 & Day 21 \\
\hline \multirow[t]{6}{*}{ Sediments* } & \multirow[t]{2}{*}{$\mathrm{Ct}$} & $0.01-0.09$ & $0.03-0.05$ \\
\hline & & $7.69-7.93$ & $0.28-0.37$ \\
\hline & Single $\mathrm{Hg}$ & $15.2-16.2$ & $16.7-17.4$ \\
\hline & Single Pyr & $432-640$ & $335-1048$ \\
\hline & \multirow[t]{2}{*}{$\mathrm{Hg}+\mathrm{Pyr}$} & $16.3-18.0$ & $17.3-17.4$ \\
\hline & & $168-182$ & $172-213$ \\
\hline \multirow[t]{6}{*}{ Overlying water** } & \multirow[t]{2}{*}{$\mathrm{Ct}$} & bdl & bdl \\
\hline & & $b d l$ & $b d l$ \\
\hline & Single $\mathrm{Hg}$ & $0.18-0.27$ & 0.001-bdl \\
\hline & Single Pyr & $1.87-5.20$ & $b d l$ \\
\hline & \multirow[t]{2}{*}{$\mathrm{Hg}+\mathrm{Pyr}$} & $0.15-0.39$ & bdl \\
\hline & & $b d l$ & $b d l$ \\
\hline \multirow[t]{6}{*}{ Pore water** } & \multirow[t]{2}{*}{$\mathrm{Ct}$} & bdl- 0.003 & bdl \\
\hline & & $b d l$ & $b d l$ \\
\hline & Single $\mathrm{Hg}$ & bdl-0.06 & bdl \\
\hline & Single Pyr & $0.29-0.38$ & bdl-0.22 \\
\hline & \multirow[t]{2}{*}{$\mathrm{Hg}+\mathrm{Pyr}$} & $0.27-0.59$ & bdl \\
\hline & & $0.50-0.54$ & $b d l$ \\
\hline
\end{tabular}

$b d l$ below detection limits

$*^{*} \mathrm{mg} / \mathrm{kg}$ d.w for $\mathrm{Hg}$ and $\mu \mathrm{g} / \mathrm{kg}$ d.w for Pyr, ${ }^{* *} \mu \mathrm{g} / \mathrm{ml}$ for $\mathrm{Hg}$ and $\mathrm{ng} / \mathrm{ml}$ for Pyr showed values below detection limits (bdl) in most samples and exposure days (Table 2). Sediments single treatments at 2 and 21 days of exposure showed values ranged from 15.2 to $17.4 \mathrm{mg} / \mathrm{kg}$ and from 432 to $1048 \mu \mathrm{g} / \mathrm{kg}$ d.w for $\mathrm{Hg}$ and Pyr respectively (Table 2). Overlying and pore water from single treatments ranged from bdl to $0.27 \mu \mathrm{g} / \mathrm{ml}$ and bdl to $5.20 \mathrm{ng} / \mathrm{ml}$ for $\mathrm{Hg}$ and $\mathrm{Pyr}$ respectively and showed a decrease in their values after 21 days of exposure (Table 2). In $\mathrm{Hg}+\mathrm{Pyr}$ treatments, sediments showed similar $\mathrm{Hg}$ values to those from single treatments ranged from 16.3 to $17.4 \mathrm{mg} / \mathrm{kg}$ d.w at 2 and 21 days of ragworm exposure respectively (Table 2). Pyr concentrations from $\mathrm{Hg}+\mathrm{Pyr}$ treatments showed lower values compared to single Pyr treatments ranged from 168 to $213 \mu \mathrm{g} / \mathrm{kg}$ d.w at 2 and 21 days of ragworm exposure respectively (Table 2). Overlying waters from mixture treatments only showed measurable concentrations of $\mathrm{Hg}$ ranged from 0.15 to 0.39 $\mu \mathrm{g} / \mathrm{ml}$ at 2 day of exposure (Table 2). Pore water from $\mathrm{Hg}$ + Pyr treatments showed values from bdl to $0.59 \mu \mathrm{g} / \mathrm{ml}$ and from 0.12 to $0.54 \mathrm{ng} / \mathrm{ml}$ for $\mathrm{Hg}$ and $\mathrm{Pyr}$ respectively, decreasing their values after 21 days of exposure (Table 2).

\section{$\mathrm{Hg}$ in $\mathrm{P}$. gualpensis tissues}

Total $\mathrm{Hg}$ concentration in ragworms from the control treatments ranged from bdl to $0.04 \mathrm{mg} / \mathrm{kg}$ w.w. (Fig. 1a). In ragworms exposed to $\mathrm{Hg}$-only, total $\mathrm{Hg}$ concentration increased significantly during the exposure period at 2 days compared to $\mathrm{Hg}$ concentrations at 21 days ( $p: 0.04$; Fig. 1a). In those exposed to $\mathrm{Hg}+\mathrm{Pyr}$, total $\mathrm{Hg}$ concentration increased from $0.17 \mathrm{mg} / \mathrm{kg} \mathrm{w} . \mathrm{w}$. at 2 days to $0.22 \mathrm{mg} / \mathrm{kg} \mathrm{w}$. w. at 21 days, and the difference between these two sampling times was not significant $(p>0.05$, Fig. 1a). The differences in total $\mathrm{Hg}$ concentration in $P$. gualpensis tissues between the treatments with $\mathrm{Hg}$-only and those with $\mathrm{Hg}+\mathrm{Pyr}$ were not significant $(p>0.05$, Fig. 1a).
Fig. 1 a Total $\mathrm{Hg}$ concentrations after $\mathrm{Hg}$-only and $\mathrm{Hg}+\mathrm{Pyr}$ exposure $(n=3)$ plus controls $(n=2)$ in Perinereis gualpensis tissues during 21 days. Measurements represent the mean \pm SE. Same color asterisks indicate significant differences $(p<0.05)$ in the same treatment vs. the initial condition (day 2). Red arrow lines indicate method detection limits reported. b 1$\mathrm{OH}-\mathrm{Pyrene}$ concentrations after Pyr-only and $\mathrm{Hg}+\mathrm{Pyr}$ exposure $(n=3-5)$ plus controls $(n$ $=2$ ) in Perinereis gualpensis tissues during 21 days. Measurements represent the mean \pm SE. Same color asterisks indicate significant differences $(p<0.05)$ in the same treatment vs. the initial condition (day 2). Red arrow lines indicate non-detected values
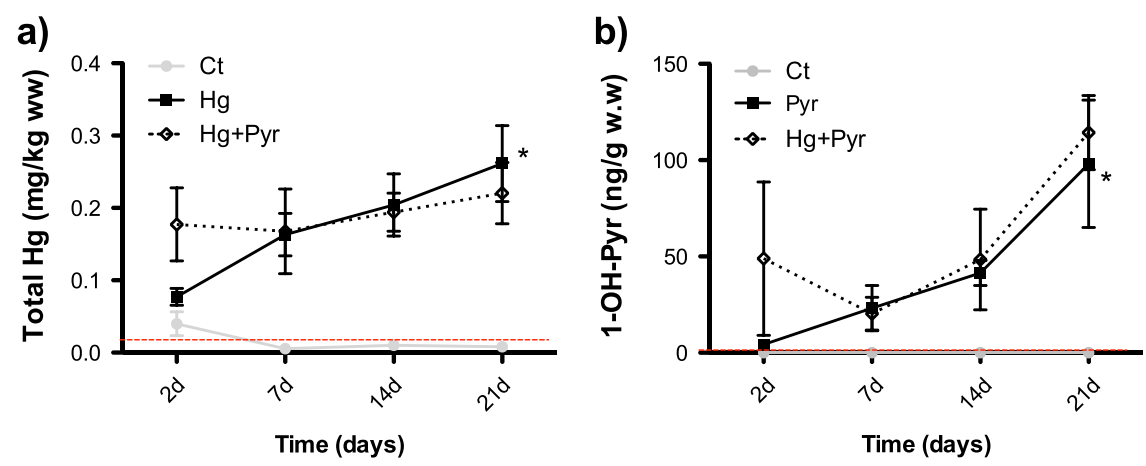


\section{1-OH-Pyr in P. gualpensis tissues}

No 1-OH-Pyr was detected in ragworms from control treatments at each sampling time, whereas significant amounts of this metabolite were quantified in organisms exposed to Pyronly and $\mathrm{Hg}+\mathrm{Pyr}$ at all exposure times (Fig. 1b). In ragworms exposed to Pyr-only, 1-OH-Pyr concentrations increased significantly at 21 days compared to 2 day exposure ( $p: 0.04$; Fig. 1b). In those exposed to $\mathrm{Hg}+\mathrm{Pyr}$, the difference between these two sampling times was not significant $(p>$ 0.05 , Fig. 1b). The differences in 1-OH-Pyr concentrations in $P$. gualpensis tissues between the treatments with Pyr-only and those with $\mathrm{Hg}+\mathrm{Pyr}$ were not significant $(p>0.05$, Fig. $1 b)$.

\section{Biochemical analysis in $P$. gualpensis}

In general, biochemical responses showed different patterns between single and combined treatments. GST activity increased significantly relative to the control treatment in ragworms exposed to $\mathrm{Hg}$-only or Pyr-only at 7 and 14 days of exposure $(p<0.01$; Fig. 2a), but decrease significantly relative to control treatment in ragworms exposed to $\mathrm{Hg}$ only for 21 days $(p<0.01$; Fig. $2 \mathrm{a})$. GST activity in ragworms exposed to $\mathrm{Hg}+\mathrm{Pyr}$ showed significant differences at 2 and 14 days of exposure respect to the control treatment and a significant increase at 2 days regarding $\mathrm{Hg}$-only and Pyr-only exposure ( $p<0.01$; Fig. 2a). GST activity after 7 , 14 and 21 days of exposure to $\mathrm{Hg}$, Pyr or $\mathrm{Hg}+$ Pyr showed significant differences respect to the initial activity ( 2 days) $(p<0.01$; Fig. 2a). Regarding GPx activity, significant differences with the control group were detected in $\mathrm{Hg}+\mathrm{Pyr}$ and $\mathrm{Hg}$-only treatments at 2 days (p: 0.04; Fig. 2b). GPx activity increased significantly after $\mathrm{Hg}$ exposure as compared to control at 14 days $(p<0.01$; Fig. 2 b) and decreased significantly at 21 days $(p<0.01$; Fig. $2 b)$. GPx activity after 7, 14 and 21 days of exposure to $\mathrm{Hg}+\mathrm{Pyr}$ showed significant decrease respect to the initial activity ( 2 days) ( $p$ : 0.03; Fig. $2 b)$ and after 21 days to $\mathrm{Hg}(p<0.01$; Fig. 2b). Total SH-groups increased significantly as compared to the control after $\mathrm{Hg}+\mathrm{Pyr}$ and $\mathrm{Hg}$-only exposure at 2 and 14 days respectively $(p<0.01 ;$ Fig. $2 c)$. No significant differences in total $\mathrm{SH}$-groups were observed between $\mathrm{Hg}+$ Pyr and the single treatments at all exposure times $(p>0.05$; Fig. 2c). Total SH-groups from ragworms exposed to $\mathrm{Hg}$ only and $\mathrm{Hg}+\mathrm{Pyr}$ at 14 and 7 days respectively were different from those at the initial conditions ( $p$ : 0.03 for $\mathrm{Hg} ; p$ $<0.01$ for $\mathrm{Hg}+$ Pyr; Fig. 2c). Total ACAP activity showed a significant decrease in total antioxidant capacity in $\mathrm{Hg}$ only and Pyr-only treatments at 14 and 21 days respectively compared to the control and $\mathrm{Hg}+\mathrm{Pyr}$ treatments $(p<0.01$ for $\mathrm{Hg} ; p$ : 0.01 for Pyr; Fig. 2d). The $\mathrm{Hg}+\mathrm{Pyr}$ mixture showed a major increase in terms of ACAP in the 1st days of exposure respect to the control and single treatments (day 2; $p<0.01$; Fig. 2d). ACAP from ragworms exposed to $\mathrm{Hg}$ only and Pyr-only at 14-21 days and $\mathrm{Hg}+\mathrm{Pyr}$ at 21 days were different from those at the initial conditions $(p<0.01$ for $\mathrm{Hg}$ and Pyr; $p$ : 0.02 for $\mathrm{Hg}+$ Pyr; Fig. 2d). Lipid peroxidation in terms of TBARS levels showed differences between single and combined exposure ( $p<0.05$; Fig. 3). TBARS levels in ragworms exposed to $\mathrm{Hg}$ showed significantly higher at 7 day of exposure than $\mathrm{Hg}+$ Pyr treatment ( $p: 0.01$; Fig. 3). TBARS levels in ragworms exposed to Hg-only and Pyr-only showed significantly higher levels of lipid peroxidation at 14 and 21 days than each control and $\mathrm{Hg}+$ Pyr treatment $(p<0.01$; Fig. 3). TBARS levels in ragworms exposed to $\mathrm{Hg}+\mathrm{Pyr}$ showed no significant
Fig. 2 Single and joint effects of $\mathrm{Hg}$ and Pyr on: a GST activity, b GPx activity, c Total SHgroups and $\mathbf{d}$ ACAP in $P$. gualpensis after 21 days of exposure. Measurements represent the mean $\pm \mathrm{SE}$. Different letters indicate significant differences $(p<0.05)$ between treatments at the same exposure time. Asterisks indicate significant differences $(p<0.05)$ in the same treatment vs. the initial condition (day 2)
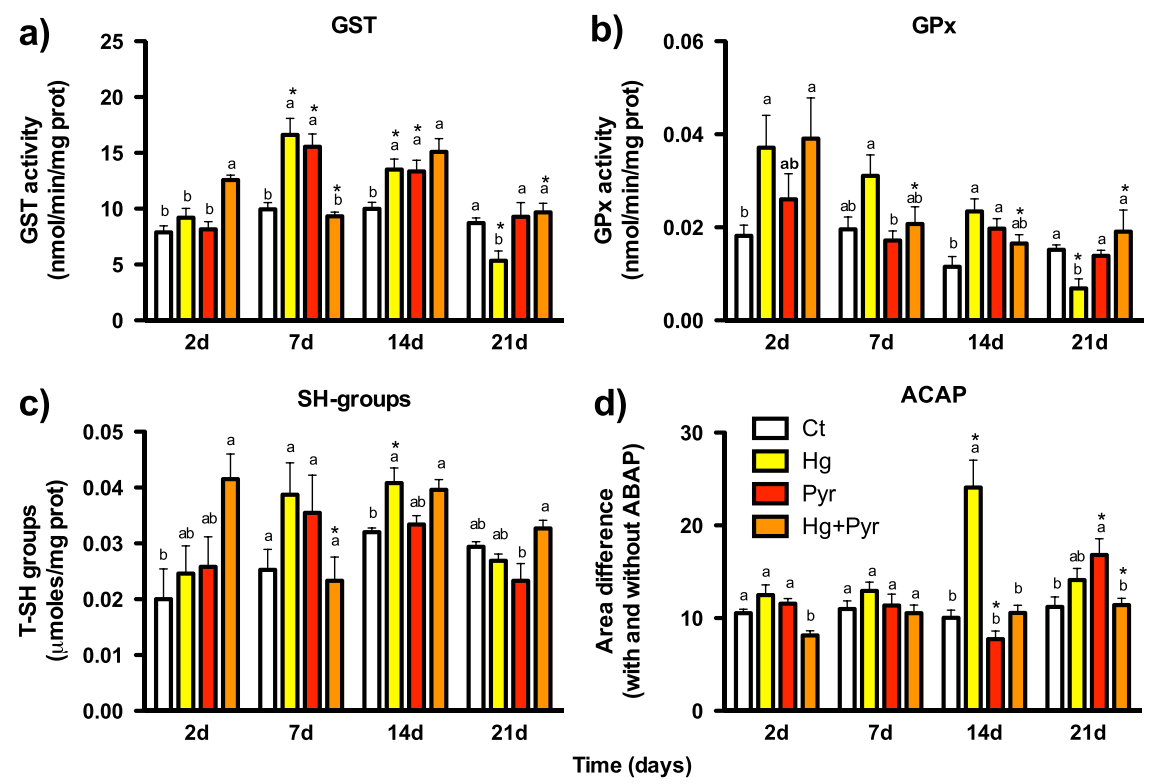


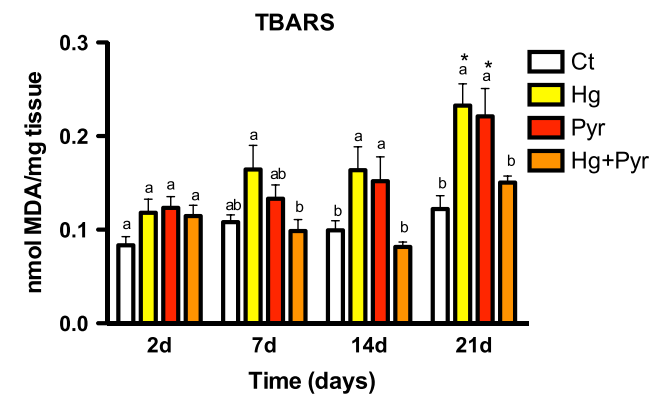

Fig. 3 Single and joint effects of $\mathrm{Hg}$ and Pyr on TBARS levels in $P$. gualpensis after 21 days of exposure. Measurements represent the mean \pm SE. Different letters indicate significant differences $(p<0.05)$ between treatments at the same exposure time. Asterisks indicate significant differences $(p<0.05)$ in the same treatment vs. the initial condition (day 2)

differences from the control groups ( $p>0.05$; Fig. 4). TBARS levels were significant different from the initial ones only in ragworms exposed to $\mathrm{Hg}$-only and Pyr-only at 21 days of exposure ( $p: 0.01$; Fig. 3).

To compare overall oxidative stress responses after single and $\mathrm{Hg}+\mathrm{Pyr}$ exposure, the PCA was made with the biochemical responses found after the different exposure times (Fig. 4). PCA analysis indicated that the first two components explained $73 \%$ of the variation, being GST activity, SHgroups, ACAP and TBARS levels the most significant variables that explained the first two principal components (Fig. 4). It also indicated that ragworms exposed to $\mathrm{Hg}+\mathrm{Pyr}$ in general showed enzymatic and non-enzymatic activities similar to those observed in controls, Hg-only and Pyr-only treatments on the first weeks of exposure (Fig. 4). In contrast, ragworms exposed to Hg-only or Pyr-only were characterized by lower antioxidant capacity and higher lipid peroxidation (mainly in $\mathrm{Hg}$-only exposure) than those exposed to $\mathrm{Hg}+\mathrm{Pyr}$ and controls at 14 and 21 days, (Fig. 4).

\section{Discussion}

Despite $\mathrm{Hg}$ concentrations in the sediments remaining relatively constant and similar in both single and mixture treatments during all exposure periods, Pyr concentrations in the sediments differed between single and mixture treatments. These results showed possible interactions between those contaminants to be taken in consideration when generating the spiked metals-PAHs sediment mixture. PAHs are known to modify and enhance solubility of metals in sediments (Almeida et al. 2008), this fact would explain the higher values of $\mathrm{Hg}$ in porewater mixture compared to single $\mathrm{Hg}$ treatment during the 1 st days of exposure. Moreover, both $\mathrm{Hg}$ and Pyr concentrations in porewater at 21 days were low and/or non-detected in both single and $\mathrm{Hg}+\mathrm{Pyr}$ treatments as compared to the initial conditions.

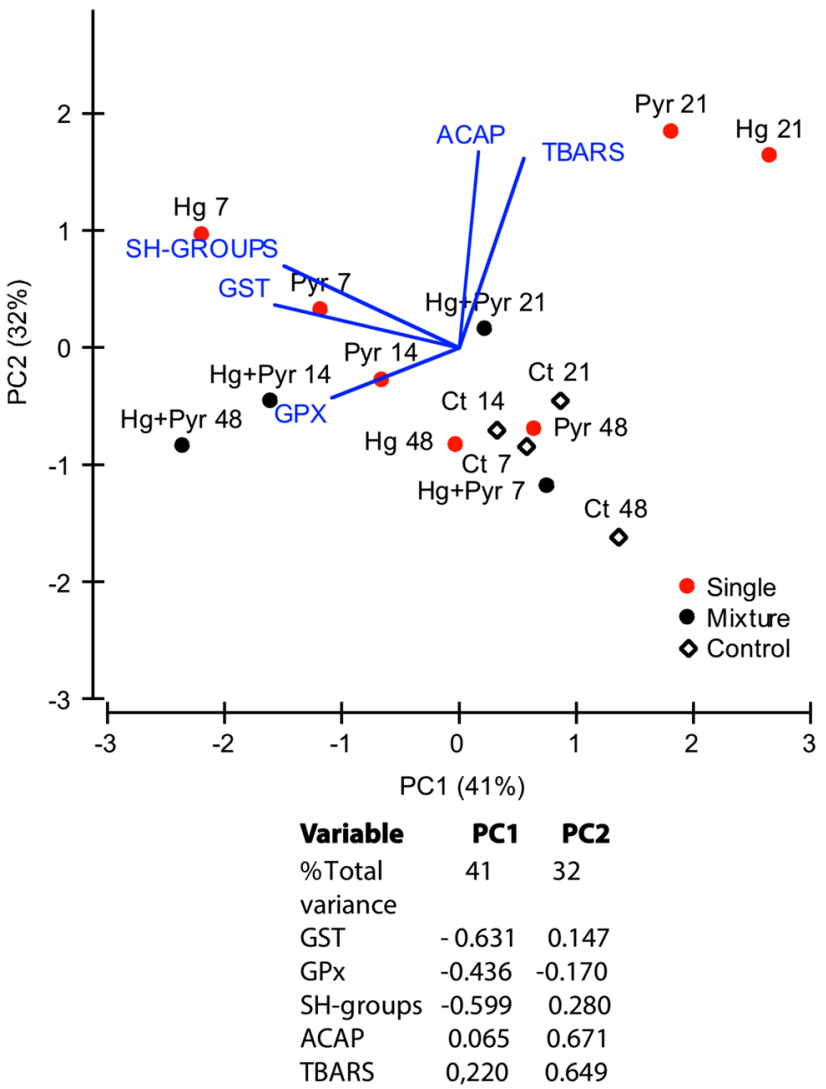

Fig. 4 Principal component analysis (PCA) for the overall oxidative stress responses observed in ragworms from control, single and $\mathrm{Hg}+$ Pyr treatments at different exposure times. The variability percentage explained by each principal axis is provided. The direction of the blue lines indicates the steepest increase in the variable, and the length indicates the strength relative to other variables. A table of variable correlations and principal component percentages (PC1, PC2) of oxidative responses is provided

Considering only the 7-21-day exposure period, during which ragworms from $\mathrm{Hg}$, $\mathrm{Pyr}$ and $\mathrm{Hg}+\mathrm{Pyr}$ treatments showed similar accumulation trends, the influence of $\mathrm{Hg}+$ Pyr in the uptake/biotransformation processes was confined only to the $1 \mathrm{st} h$ /days of exposure. On the other hand, some authors have reported different 1-OH-Pyr concentrations when animals are exposed to Pyr together with other pollutants (Broerse et al. 2012; Oliveira et al. 2013). Moreover, in some invertebrate species, high and early Pyr exposure leads to high metabolization rates (Richardson et al. 2008). As observed in other annelids, the occurrence of 1-OH-Pyr metabolites in $P$. gualpensis tissues emerges as an effective biomarker of exposure to PAHs (Giessing et al. 2003) and suggests that the cytochrome P450 (Phase I) system involved in the metabolism of xenobiotics exhibits relatively high activity in this species.

Single Pyr exposure triggers oxidative stress responses of some polychaeta, as reported by some authors in aquatic organisms (Almeida et al. 2012; Luís and Guilhermino 
2012). GST activation by this PAH could be related to the biotransformation of Pyr by catalyzing the conjugation of metabolite(s) generated in phase I with glutathione and/or the increase in GST activity in response to Pyr-induced oxidative stress (Luís and Guilhermino 2012). Nevertheless, the decreases observed in the present study in total antioxidant capacity and enhanced lipid peroxidation in ragworms at the end of Pyr exposure indicate harmful single effects at the environmental concentrations studied. However, the Hg-only exposure caused either induction or inhibition processes in most of the responses evaluated. Regarding GST and GPx activity, the activation and subsequent inhibition by the $\mathrm{Hg}$-only exposure revealed the high disrupting capacity of $\mathrm{Hg}$ in glutathione-dependent enzymes (Colacevich et al. 2011). It is known that $\mathrm{Hg}$ causes oxidative stress via $\mathrm{H}_{2} \mathrm{O}_{2}$ production, where GPxs are crucial for peroxide removal and many GST isoforms possess peroxidase-like activity (Rodrigues et al. 2013). As the main thiol pool, glutathione contains SH-groups that play a role in intracellular $\mathrm{Hg}$ sequestration (Kovářová and Svobodová 2009). So, $\mathrm{Hg}^{2+}$ ions have a high affinity for SH-groups, and it has been reported that non-organic $\mathrm{Hg}$ compounds are able to induce the formation and subsequent depletion of SH compounds in aquatic organisms (Colacevich et al. 2011; Wu and Wang 2012). Decreased total antioxidant capacity and high levels of lipid peroxidation in polychaetes after the $\mathrm{Hg}$-only exposure relates to the decreased levels of antioxidant/detoxification enzymes. The inhibition or down-regulated responses of crucial enzymes could be responsible for the oxidative damage caused by $\mathrm{Hg}$ forms, indicating that enzyme inhibition represents at least an important mechanism by which $\mathrm{Hg}$ causes deleterious effects (Rodrigues et al. 2013; Gauthier et al. 2014).

In contrast to that observed in the single treatments, polychaetes from the $\mathrm{Hg}+\mathrm{Pyr}$ treatment reflected different patterns of the above-mentioned responses and suggest that $>$ PEL Hg concentrations in sediments could exerts different toxic scenarios in the presence of certain $<$ PEL Pyr concentrations. Since some of the biochemical responses observed during the 21 days of the experiment are idiosyncratic (e.g. total SH) and TBARS levels from posterior body end may be different from the rest of the body (DíazJaramillo et al. 2011), the predictive value of these responses at this exposure time are questionable. The different toxic interactions suggested in this work doesn't represent non-adverse scenarios, since long-term exposures to high levels of $\mathrm{Hg}$ and organic pollutants in sediments could trigger more ecological relevant adverse effects on this specie (Díaz-Jaramillo et al. 2011). On this basis, low densities, low adult survival and poor reproductive fitness comparing to non-impacted $P$. gualpensis populations were the main observed effects from this multi-polluted scenario (Díaz-Jaramillo et al. 2015).
However, equilibration time and medium-term exposure used following spiking sediments, would lead to $\mathrm{Hg}$ methylation in sediments. Unfortunately, $\mathrm{MeHg}$ concentrations in the sediments and worms were not determined, since inorganic forms as $\mathrm{HgCl}_{2}$ are used for maximal $\mathrm{Hg}$ bioavailability to methylation process (Davis et al. 1997; Bloom and Preus 2003). Instead of spiked inorganic mercury, the lower toxicity of $\mathrm{Hg}+\mathrm{Pyr}$ compared to Hg-only, could probably be due to the fact that Pyr impacts on $\mathrm{MeHg}$ production in sediments.

Finally, different types of mixtures between PAHs and metals and their concentrations, the exposure medium, test organism, test duration and endpoints studied result in a wide range of interactive effects and predominantly more than additive type responses (Shen et al. 2006, Gauthier et al. 2014). Unfortunately neither $\mathrm{Hg}$ nor Pyr studies were reported in similar test media or exposure time in order to obtain comparative results. Our preliminary results suggest the need for further studies to elucidated $\mathrm{Hg}$ interactions with other chemicals highlights the complexity that take place in multi-polluted sediments.

\section{Conclusions}

Results showed differences between single and combined treatments in terms of $P$. gualpensis enzymatic and nonenzymatic oxidative stress responses. An early enzymatic and non-enzymatic activation with the absence of oxidative damage in the mid-term suggests different oxidative stress scenarios for each contaminant. Single exposure to $\mathrm{Hg}$ elicited more relevant toxicological effects, often resulting in inhibition of some antioxidant/detoxification enzymes and enhanced lipid peroxidation. Our results suggest the importance of time-scale and tracking contaminant concentrations in elucidating potential effects on benthic species produced by this type of chemical mixture.

Acknowledgements This article is part of Díaz-Jaramillo's PhD thesis, supervised by R. Barra and funded by a $\mathrm{PhD}$ fellowship "Corporación Red Universitaria Cruz del Sur (Chile)". FONDAP CRHIAM CONICYT CHILE 15130015 is also acknowledged. We would also like to thank Laboratorio Costero de Recursos AcuáticosCalfuco, Claudio Bravo, José M. Monserrat, Gilberto Fillman, Sandor Mulsow, Alice Turner, Soraya Céspedes, Ana Araneda, Solange Jara, Francesca Mitton and Mariana Gonzalez for the support during the laboratory assays and field sampling. This study was partially funded by ANPCyT of Argentina (Dr. Pedro Carriquiriborde, PICT-1598).

\section{Compliance with ethical standards}

Conflict of interest The authors declare that they have no competing interests.

Ethical approval This article does not contain any studies with human participants or animals performed by any of the authors. 


\section{References}

Ahmad I, Oliveira M, Pacheco M, Santos MA (2005) Anguilla anguilla L. oxidative stress biomarkers responses to copper exposure with or without $\beta$-naphthoflavone pre-exposure. Chemosphere 61:267-275. doi:10.1016/j.chemosphere.2005.01.069

Almeida CMR, Mucha AP, Delgado MFC et al. (2008) Can PAHs influence $\mathrm{Cu}$ accumulation by salt marsh plants? Mar Environ Res 66:311-318. doi:10.1016/j.marenvres.2008.04.005

Almeida JR, Gravato C, Guilhermino L (2012) Challenges in assessing the toxic effects of polycyclic aromatic hydrocarbons to marine organisms: a case study on the acute toxicity of pyrene to the European seabass (Dicentrarchus labrax L.). Chemosphere 86:926-937. doi:10.1016/j.chemosphere.2011.10.059

Amado LL, Garcia ML, Ramos PB et al. (2009) A method to measure total antioxidant capacity against peroxyl radicals in aquatic organisms: application to evaluate microcystins toxicity. Sci Total Environ 407:2115-2123. doi:10.1016/j.scitotenv.2008.11.038

American Public Health Association, American Water Works Association, Water Environment Federation (2012) Standard methods for the examination of water and wastewater. Stand Methods 741. 10.2105/AJPH.51.6.940-a

Amiard-Triquet C, Rainbow PS (2009) Environmental assesment of estuarine ecosystems A case study. CRC press, Boca Raton

Banni M, Bouraoui Z, Clerandeau C et al. (2009) Mixture toxicity assessment of cadmium and benzo[a]pyrene in the sea worm Hediste diversicolor. Chemosphere 77:902-906. doi:10.1016/j. chemosphere.2009.08.041

Bouraoui Z, Banni M, Ghedira J et al. (2009) Evaluation of enzymatic biomarkers and lipoperoxidation level in Hediste diversicolor exposed to copper and benzo[a]pyrene. Ecotoxicol Environ Saf 72:1893-1898. doi:10.1016/j.ecoenv.2009.05.011

Bloom NS, Preus E (2003) Anoxic sediment incubations to assess the methylation potential of mercury contaminated solids. In: Tremblay H, Locat J, Galvez-Cloutier R (eds) Proceedings of the 2nd International Symposium on Contaminated Sediments; 2003 May 26-28, Quebec, Canada; p 331-336.

Broerse M, Oorsprong H, Van Gestel CAM (2012) Cadmium affects toxicokinetics of pyrene in the collembolan Folsomia candida. Ecotoxicol 21:795-802. doi:10.1007/s10646-011-0839-2

Cachot J, Geffard O, Augagneur S et al. (2006) Evidence of genotoxicity related to high PAH content of sediments in the upper part of the Seine estuary (Normandy, France). Aquat Toxicol 79:257-267. doi:10.1016/j.aquatox.2006.06.014

CCME (Canadian Council of Ministers of the Environment) (2002) Canadian sediment quality guidelines for the protection of aquatic life: summary tables. Updated 2002. Canadian Environmental Quality Guidelines (1999). Canadian Council of Ministers of the Environment, Winnipeg

Colacevich A, Sierra MJ, Borghini F et al. (2011) Oxidative stress in earthworms short- and long-term exposed to highly $\mathrm{Hg}$ contaminated soils. J Hazard Mater 194:135-143. doi:10.1016/j. jhazmat.2011.07.091

Davis A, Bloom NS, Que Hee SS et al. (1997) The environmental geochemistry and bioaccessibility of mercury in soils and sediments: a review. Risk Anal 17:557-569. doi:10.1111/j.15396924.1997.tb00897.x

Díaz-Jaramillo M, Martins da Rocha A, Gomes V et al. (2011) Multibiomarker approach at different organization levels in the estuarine Perinereis gualpensis (Polychaeta; Nereididae) under chronic and acute pollution conditions. Sci Total Environ 410411:126-135. doi:10.1016/j.scitotenv.2011.09.007

Díaz-Jaramillo M, Muñoz C, Rudolph I et al. (2013) Seasonal mercury concentrations and $\delta 15 \mathrm{~N}$ and $\delta 13 \mathrm{C}$ values of benthic macroinvertebrates and sediments from a historically polluted estuary in south central Chile. Sci Total Environ 442:198-206. doi:10.1016/ j.scitotenv.2012.10.039

Díaz-Jaramillo M, Sandoval N, Barra R et al. (2015) Spatio-temporal population and reproductive responses in Perinereis gualpensis (Polychaeta: Nereididae) from estuaries under different anthropogenic influences. Chem Ecol 1-12. 10.1080/02757540.2015. 1022535

Gauthier PT, Norwood WP, Prepas EE, Pyle GG (2014) Metal-PAH mixtures in the aquatic environment: A review of co-toxic mechanisms leading to more-than-additive outcomes. Aquat Toxicol 154:253-269. doi:10.1016/j.aquatox.2014.05.026

Giessing AMB, Mayer LM, Forbes TL (2003) Synchronous fluorescence spectrometry of 1-hydroxypyrene: a rapid screening method for identification of PAH exposure in tissue from marine polychaetes. Mar Environ Res 56:599-615. doi:10.1016/S01411136(03)00045-X

Habig WH, Jakoby WB (1981) [51] Assays for differentiation of glutathione S-Transferases. Methods Enzymol 77:398-405. doi:10.1016/S0076-6879(81)77053-8

Hutchins C (2005) Geochemical Response of Cu, Zn \& Cd Spiked sediment: A comparison of metal spiking procedures evaluated using whole sediment toxicity test. School of Enviornmental and Applied Sciences. Griffith University, Queensland, p 243, https:// www120.secure.griffith.edu.au/rch/items/7697ff4c-be5e-17184891-f8ef013049d6/1/

Kopecka-Pilarczyk J, Correia AD (2009) Biochemical response in gilthead seabream (Sparus aurata) to in vivo exposure to pyrene and fluorene. J Exp Mar Bio Ecol 372:49-57. doi:10.1016/j. jembe.2009.02.004

Kovářová J, Svobodová Z (2009) Can thiol compounds be used as biomarkers of aquatic ecosystem contamination by cadmium? Interdiscip Toxicol 2:177-183. doi:10.2478/v10102-009-0013-3

Luís LG, Guilhermino L (2012) Short-term toxic effects of naphthalene and pyrene on the common prawn (Palaemon serratus) assessed by a multi-parameter laboratorial approach: mechanisms of toxicity and impairment of individual fitness. Biomarkers 17:275-285. doi:10.3109/1354750X.2012.666765

Lund B-O, Miller DM, Woods JS (1993) Studies on Hg(II)-induced $\mathrm{H} 2 \mathrm{O} 2$ formation and oxidative stress in vivo and in vitro in rat kidney mitochondria. Biochem Pharmacol 45:2017-2024. doi:10. 1016/0006-2952(93)90012-L

MacDonald DD, Ingersoll CG, Berger TA (2000) Development and evaluation of consensus-based sediment quality guidelines for freshwater ecosystems. Arch Environ Contam Toxicol 39:20-31. doi: $10.1007 / \mathrm{s} 002440010075$

Mai B-X, Fu J-M, Sheng G-Y et al. (2002) Chlorinated and polycyclic aromatic hydrocarbons in riverine and estuarine sediments from Pearl River Delta, China. Environ Pollut 117:457-474. doi:10. 1016/S0269-7491(01)00193-2

Maria VL, Bebianno MJ (2011) Antioxidant and lipid peroxidation responses in Mytilus galloprovincialis exposed to mixtures of benzo(a)pyrene and copper. Comp Biochem Physiol Part C Toxicol Pharmacol 154:56-63. doi:10.1016/j.cbpc.2011.02.004

Mason R, Bloom N, Cappellino S et al. (1998) Investigation of porewater sampling methods for mercury and methylmercury. Environ Sci Technol 32:4031-4040. doi:10.1021/es980377t

Newman MC, Unger MA (2003) Fundamentals of Ecotoxicology, 2nd edn. Lewis Publishers, Inc, Boca Raton, FL, p 458

Oakes KD, Van Der Kraak GJ (2003) Utility of the TBARS assay in detecting oxidative stress in white sucker (Catostomus commersoni) populations exposed to pulp mill effluent. Aquat Toxicol 63:447-463

Oliveira M, Ribeiro A, Hylland K, Guilhermino L (2013) Single and combined effects of microplastics and pyrene on juveniles $(0$ + group) of the common goby Pomatoschistus microps (Teleostei, 
Gobiidae). Ecol Indic 34:641-647. doi:10.1016/j.ecolind.2013. 06.019

Ouddane B, Mikac N, Cundy AB, et al (2008) A comparative study of mercury distribution and methylation in mudflats from two macrotidal estuaries: The Seine (France) and the Medway (United Kingdom). Appl Geochemistry 23:618-631. doi:10.1016/j. apgeochem.2007.11.001

Pozo K, Perra G, Menchi V et al. (2011) Levels and spatial distribution of polycyclic aromatic hydrocarbons (PAHs) in sediments from Lenga Estuary, central Chile. Mar Pollut Bull 62:1572-1576. doi:10.1016/j.marpolbul.2011.04.037

Richardson BJ, Mak E, De Luca-Abbott SB et al. (2008) Antioxidant responses to polycyclic aromatic hydrocarbons and organochlorine pesticides in green-lipped mussels (Perna viridis): do mussels "integrate" biomarker responses? Mar Pollut Bull 57:503-514. doi:10.1016/j.marpolbul.2008.02.032

Rodrigues NR, Nunes MEM, Silva DGC et al. (2013) Is the lobster cockroach Nauphoeta cinerea a valuable model for evaluating mercury induced oxidative stress? Chemosphere 92:1177-1182. doi:10.1016/j.chemosphere.2013.01.084

Sedlak J, Lindsay RH (1968) Estimation of total, protein-bound, and nonprotein sulfhydryl groups in tissue with Ellman's reagent. Anal Biochem 25:192-205. doi:10.1016/0003-2697(68)90092-4

Shen G, Lu Y, Hong J (2006) Combined effect of heavy metals and polycyclic aromatic hydrocarbons on urease activity in soil. Ecotoxicol Environ Saf 63:474-480. doi:10.1016/j.ecoenv.2005. 01.009

Sies H, Koch OR, Martino E, Boveris A (1979) Increased biliary glutathione disulfide release in chronically ethanol-treated rats. FEBS Lett 103:287-290. doi:10.1016/0014-5793(79)81346-0
Stoichev T, Amouroux D, Wasserman JC et al. (2004) Dynamics of mercury species in surface sediments of a macrotidal estuarinecoastal system (Adour River, Bay of Biscay). Estuar Coast Shelf Sci 59:511-521. doi:10.1016/j.ecss.2003.10.007

UNEP; IOC; IAEA. (1992) Determination of petroleum hydrocarbons in sediments. Ref Methods Mar Pollut Stud [S.1] 20:7

UNEP (2013) Global mercury assessment 2013: Sources, emissions, releases and environmental transport. UNEP Chemicals Branch, Geneva, Switzerland

USEPA. (1991) Method 245.5, mercury in sediments by cold vapor (CV/AAS). Revision 2.3. US Environmental Protection Agency Ofice of Research and Development, Cincinnati

Vega-López A, Ayala-López G, Posadas-Espadas BP et al. (2013) Relations of oxidative stress in freshwater phytoplankton with heavy metals and polycyclic aromatic hydrocarbons. Comp Biochem Physiol A Mol Integr Physiol 165:498-507. doi:10. 1016/j.cbpa.2013.01.026

Wang L, Pan L, Liu N et al. (2011) Biomarkers and bioaccumulation of clam Ruditapes philippinarum in response to combined cadmium and benzo[ $\alpha]$ pyrene exposure. Food Chem Toxicol 49:3407-3417. doi:10.1016/j.fct.2011.06.015

Wu Y, Wang WX (2012) Thiol compounds induction kinetics in marine phytoplankton during and after mercury exposure. J Hazard Mater 217-218:271-278. doi:10.1016/j.jhazmat.2012.03.024

Yañez J, Guajardo M, Miranda C et al. (2013) New assessment of organic mercury formation in highly polluted sediments in the Lenga estuary, Chile. Mar Pollut Bull 73:16-23. doi:10.1016/j. marpolbul.2013.06.015 